non habet imperium, de jure imperii, de jure gestionis, in rem, lex loci laboris, lex loci delegationis.

И увеличивать объема книги при этом не нужно ни на одну страницу, так как последняя страница "словаря латинских юридических изречений и выражений” осталась почти пустой.

С учетом вышеизложенных замечаний новый учебник латинского языка для юристов был бы идеальным и поистине "золотым" для студентов-юристов не только по цвету букв и орнамента на обложке, но и по внутреннему содержанию.

M. B. $\mathrm{M}$ a c a e $\mathrm{B}$, аспирант Симферопольского государственного университета, член Российской ассоциации международного права

B. M. M a c a e B, преподаватель международного права и латыни г. Симферополь

Таврического экологического института

Рецензия поступила в редакцию в апреле 1999 z.

\title{
ФОРМИРОВАНИЕ ПАРЛАМЕНТСКОГО КОНТРОЛЯ НАД ВОЕННОЙ СФЕРОЙ
}

(К выгходу сборника аналитических докладов "Парламентский контроль нал военной сферой в новых независимьх государствах", под общей редакцией А.И.Никитина. - М., 1998. - 301 с.)

Авторы сборника рассматривают одно из актуальньгх награвлений формирования основ демократического общества - организацию парламентского контроля над военной сферой. Трудности, с которыми сталкиваются в своем развитии государства-участники СНГ, не исключают возможности ослабления или даже утраты контроля над Вооруженными силами, сниожения гарантий подчинения военной политики более широким национальным интересам, что несет в себе непосредственную угрозу демократии. Способами создания баланса в отношениях военной и гражданских сфер общества, наряду с другими, являются проведение аналитических исследований и обмен накопленным опьтом парламентской деятельности. Работу, направленную на реализацию аналитического проекта сопоставления моделей гражданского, в том числе парламентского контроля над военной сферой в разнъх государствах, возглавили российский Центр политических и международных исследований (ЦПМИ) и Департамент исследований проблем мира Брэдфордского университета (Великобритания). Результаты проделанной работы и представлены в настоящем сборнике.

Рассматривая международную практику развития парламентского надзора и контроля за деятельностью Вооруженньх сил и исполнительной власти в военной сфере, профессор Брэдфордского университета 
О.Грин и преподаватель того же университета М.Чалмерс обрацаются к опыту США, где Конгресс обладает значительной непосредственной властью в определении военной политики и военньг расходов (c.11).

На основе обобщения опыта парламентской деятельности ряда стран в области контроля над военной сферой авторы формулируют некоторые основные приоритеты развития парламентского контроля для новьх независимых стран, определяюшего роль парламента, средств массовой информации, неправительственных организаций в регулировании деятельности Вооруженных сил и исполнительной власти; выработку механизма парламентского контроля, включаюшего в себя порядок создания и деятельности парламентских комитетов, публикацию ежегодньх офищиальньх докладов об оборонной политике, проведение независимого аудита оборонньх расходов и т.п.; - предоставление в рамках мер по укрепленио доверия и безопасности информации военного характера международным органам и правительствам других стран; определение роли парламента в разработке оборонньх программ и планов; - оуцествление парламентского контроля над государственным регулированием военного экспорта (с. 14-18).

В сборнике публикуются извлечения из Кодекса поведения, касающегося военно-политических аспектов безопасности, принятого ОБСЕ в 1994 году в Будапеште (с. 23-26). Обрашение к данному документу представляется весьма своевременным, как к одному из ориентиров, $\mathrm{K}$ которому должны стремиться новые независимые государства при формировании эффективной системы гражданского контроля над военной сферой.

Основное место в сборнике отводится освещению проблем и практике формирования основ гражданского контроля над военной сферой в странах Содружества Независимых Государств.

В докладе эксперта по странам СНГ Армянского центра стратегических и национальных исследований Б.Л.Садояна бальшое внимание уделяется истории военного строительства (с. 27) и анализу военного законодательства республики (с. 28-30). Рассматривая трудности формирования системы парламентского контроля в этой сфере, автор подчеркивает роль контрольной палаты парламента, одной из функций которой является оценка исполнения бюджета (с. 33). В докладе приводятся и примеры таких прогрессивных во всех отношениях форм законодательного воздействия на военную политику, как дебаты по поводу проектов законов, процедуры публичной политики и другие (с. 34).

Рассматривая проблемы демократизации в военной сфере, председатель Комиссии по международным делам и национальной безопасности Национального Собрания Республики Беларусь Н.И.Чергинец отмечает необходимость принятия пакета военного законодательства военного кодекса (с. 42), а также обрашает внимание на желательность разработки модельных законодательных актов в военной сфере (с. 46).

Директор Международного института политических исследований (г.Минск) В.Э.Поздняк в своем докладе дает сравнительную характеристику структуры и практики парламентского контроля в военной сфере в периоды существования различных форм правления в Республике Беларусь. Период парламентской республики 1992-1994 гг. проте- 
кал, по мнению автора, при заметном усилении внимания и контроля законодателей над военной сферой (с. 51). Переход в 1994 году К президентской республике связывается с постепенным ослаблением законодательной втасти в пользу исполнительной, в том числе и в военной сфере (с. 58). Отмечая серьезные трудности формирования гражданского общества как главной предпосылки существования гражданского контроля, В.Э.Поздняк видит выход из создавшегося положения в расширении прав законодательной власти (с. 52). Аналогичную точку зрения на проблему гражданского контроля над военной сферой высказывает и главный эксперт Национального центра стратегических инициатив Восток-Запад (г.Минск) В.Караблевич (с. 61, 63, 66).

Рассматривая особый характер условий, в которьх формируется система гражданского контроля над военной сферой в Республике Беларусь, научный сотрудник Национального центра Восток-Запад С.Агаронова отмечает, что парламент Белоруссии располагает определенными механизмами контроля за деятельностью исполнительной власти в военной сфере (с. 76). Значительную роль в таком механизме автор отводит деятельности политических партий и неправительственных организаций (с. 78-79). Особое внимание в докладе С.Агароновой уделяется проблеме контроля за деятельностью правоохранительных органов и специальньх служб, отмечая, что это требует четкого законодательного определения задач и функций силовых структур, порядка и правил их применения, в том числе и в чрезвычайных .обстоятельствах (с.85).

Анализируя опьт парламентариев Грузии по контролю над военной сферой, директор Евроатлантического центра Грузии Л.Алапишвили особое внимание обращает на принятый закон "О группе доверия Парламента Грузии”. Созданная этим законом группа доверия осуществляет бюджетный контроль над военными и иными ведомствами, деятельность и бюджет которых полностью или частично засекречены (с. 92). Механизм деятельности группы вктючает, в том числе, и процедуру рассекречивания информации в случае совершения правонарушений в указанных ведомствах.

В докладе консультанта Казахстанского института стратегических исследований Б.Р.Ахметталиева особое значение уделяется расширению межпарламентских связей в рамках международных организаций СНГ, ОБСЕ, а также двустороннему сотрудничеству парламентариев Казахстана в первую очередь с ближайшими соседями Россией и Китаем (с. 99-101). Друтим шагом демократизации военньх сфер государственной жизни является расширение практики привлечения гражданских сотрудников к решению вопросов финансово-экономического характера, развития оборонной промышшенности, вооружения и т.д. (с. 103). Следует отметить большую роль общественности в создании системы гражданского контроля над военной сферой, и , в частности, создание нового института Совета независимых представителей при министерстве обороны Казахстана (с. 104).

Активное участие в обсуждении проблемы приняли представители Киргизии. Рассматривая практику парламентского контроля над военной сферой в республике, начальник Центрального управления соци- 
ально-правовой и воспитательной работы Министерства обороны М.М.Койбулаев отметил такие ее формы, как заслушивание отчета министра обороны на сессии Собрания народных представителей, проведение парламентских слушаний по вопросу реформирования Вооруженных сил, использование права депутатского запроса в адрес руководства министерства обороны и др. (с. 109-110). Выступивший член Комиссии по военным вопросам парламента Киргизии Э.Э.Оролбаев отметил и такую форму парламентской практики в данной области, как инспектирование соединений и частей депутатскими группами (с. 119). Сотрудник Международного института стратегических исследований при Президенте Кыргызской Республики А.К.Абылгазиева в своем докладе отмечает, что формирование системы эффективного грахданского контроля над вооруженными силами преследует ряд целей, как то: создание механизма контроля, исключающего возможность произвольных, незаконньх действий со стороны армии; - реализацию законодательства по обеспечению социальных гарантий и правовой защиты военнослужаших и др. Одним из способов достижения названных целей в настоящее время докладчик видит участие парламента в разработке программ и планов военного ведомства и военной политики (с. 126-127).

Проблемы формирования основ демократического контроля над военной сферой стоят и перед Республикой Молдова. Во многом они сходны с теми же трудностями, с которыми столкнулись и другие независимые государства в постсоветском пространстве. В то же время молдавское общество разделяет и надежды своих соседей на успешное завершение демократических преобразований, в том числе и в области военного строительства. Как отмечает в своем выступлении директор Евроатлантического центра Республики Молдова Н.Киртоаке, армия может стать элементом стабильности при условии преодоления ею состояния обособленности от обшества (с. 134). Уменьшить разрыв между военными и обществом может лишь эффективно действуюший механизм гражданского, и в первую очередь, парламентского контроля над военной сферой. Опыт функционирования молдавского парламента дает такой пример осушествления оперативного контроля за деятельностыю армии и структур управления ею, как заслушивание в парламенте руководства силовых структур на так называемом Часе правительства (c. 144). В республике определенную роль в формировании системы гражданского контроля играют обшественные движения и организации, например, фонд "Vitorul", Центр национальньх и международньх исследований "Реrspectiva", организация пацифистов Молдовы и др. (c. 148). Особенностью участия Молдовы в СНГ является то, что республика воздержалась от подписания документов, относящихся к военному сотрудничеству и созданию общих структур безопасности в рамках Содружества. В свою очередь это снижает, как подчеркивается в докладе Н.Киртоаке, возможность унификации национального законодательства на основе разрабатываемых Межпарламентской ассамблеей СНГ модельньх правовых актов в этой области (с. 152).

Российская Федерация не исктючение в ряду государств-участников СНГ, и проблемы в области формирования системы гражданского 
контроля над вооруженными силами и силовыми ведомствами в ней столь же очевидны, как и потребность в их разрешении.

В представленном сборнике проекте Федерального Закона О гражданском контроле над военной организацией Российской Федерации (с. 155-170) и комментарии к нему советника Комитета Госдумы по обороне С.Г.Маслюка предпринята попытка убедить широкую обшественность в целесообразности такого документа и тех очевидных возможностях, которые представляются в случае его принятия. Приведем, к примеру, хотя бы то положение, что по степени своего влияния на военно-силовые структуры законодательные органы управления уравнены с органами исполнительной власти (ст. 5, 6, 9 проекта Закона). Безусловно, достижение такой цели повысит эффективность гражданского контроля над силовыми ведомствами и создаст дополнительные гарантии стабитьности общественных отношений.

Рассматривая положение дел в этой области у нас в стране, професcop МГИМО (У) МИД РФ Ю.Е.Федоров выцеляет основные параметры (элементы) гражданского контроля: политический нейтралитет Вооруженных сит и правоохранительных институтов; деятельность военных ведомств и силовых структур только на основе и в рамках закона; приоритет гражданских институтов при принятии решений по военным вопросам; рассмотрение споров и конфликтов непрофессионального характера в рамках гражданских институтов; максимально возможное информирование обшественности о положении дел в армии, военной промышленности и т.д.; взаимосвязь армии с гражданским обществом (c. 183-184). Действие названных элементов в совокупности и опредејяет состояние отношений межпу обществом и армией.

Анализируя роль законодательной власти в обеспечении гражданского контроля над Вооруженғыми силами России, Ю.Е.Федоров остро критикует парламент за его позицию, направленную в ряде случаев на лоббирование военных крутов, настаивающих на высоких, непосильных для страны ассигнованиях на оборону. В этой связи автор отмечает необходимость поиска для России таких форм и методов гражданского контроля, которые бы учитывали ее политическую специфику (с. 193).

Характеризуя полномочия Президента по установлению политического контроля над Вооруженными силами, автор в то же время подчеркивает, что это обстоятельство перекрывает перспективы становления эффективного демократического контроля над силовыми структурами (с. 189). Автор анапизирует возможности и других структур исполнительной власти по контролю над Вооруженными силами: Администрации президента, Совета Безопасности, военной контрразведки.

Рассматривая механизм парламентского контроля за деятельностью силовьх структур в России, профессор Военной Академии Генерального штаба ВС О.А. Бельков отмечает, что причины его несовершенства могут быть объяснены такими обстоятельствами, как несовершенство Конституции, профессиональная непригодность парламентариев, отсутствие общественного согласия по многим принципиальыы военно-политическим вопросам (с. 218-219).

Отдельные проблемы обеспечения общественного контроля над военной сферой применительно к конкретному государству были затро- 
нуты в докладах заведуюшего отделом Центра стратегических исследований при президенте Республики Таджикистан В.М.Зайченко, зав. Сектором стран СНГ Института стратегических исследований при президенте Республики Узбекистан М.М.Фазылова и руководителя группы экспертов украинского Центра экономических и политических исследований В.А.Гречининова.

Своими взглядами на рассматриваемую проблему, опьтом влияния парламента на военную политику поделились представители развитьх европейских демократий: профессор школы европейских и международных исследований Университета Ридинг (Великобритания) К. Блат, член палаты общин парламента Великобритании Д.Брюс, член Риксдага от Христианско-демократической партии (Швеция) Д.Эрикссон.

Собранные в данной книге доклады характеризуют опыт стран СНГ в деле развития гражданского и, в частности, парламентского контроля над военной сферой. С целью ознакомления с мировой практикой в этой области в сборник включены также работы парламентариев ряда западноевропейских стран, которые отмечают как достижения, так и проблемы стран ЕС в развитии отношений между гражданским обшеством и военными и силовыми структурами государств. Представленные в докладах точки зрения, взгляды и опьт могут быть использованы как в процессе формирования системы парламентского контроля над военной сферой в новых независимых государствах, так и в научно-исследовательской работе в этой области.

В.С в и н а р е в, кандидат юридических наук

Статья поступила в редакцию в марте 1999 года.

\section{ОТ КУЛЬТУРЫ ВОЙНЫ К КУЛЬТУРЕ МИРА}

(Год 2000. На пути к культуре мира и ненасилия. Материалы международной научно-практической конференции "От стереотипов войны к идеалам мира через культуру и образование". Москва, 8- 9 декабря 1997 г. - М. 1998. - 271 с.)

Проведенная в Москве международная конференция по проблемам культуры мира была организована в рамках проекта ЮНЕСКО "На пути к культуре мира", разработанного этой организацией в 1993 г. Ее организаторами выступили ЮНЕСКО, Министерство Российской Федерации по делам национальностей и федеративным отношениям и Российский институт культурологии и Министерство культуры России. Рецензируемый сборник состоит из докладов и выступлений участников конференции, ее итоговых документов и материалов ЮНЕСКО по вопросам культуры мира.

Наша страна отнюдь не случайно была избрана местом проведения 